Article

\title{
The Fragility of Gender Equality Policies in Spain
}

\author{
Octavio Salazar Benítez \\ Public and Economic Law Department, University of Córdoba, Plaza de Puerta Nueva, s/n, 14002 Córdoba, \\ Spain; octavio@uco.es \\ Academic Editor: Nancy Naples \\ Received: 15 December 2015; Accepted: 20 April 2016; Published: 26 April 2016
}

\begin{abstract}
Within the last decade, Spain has become a model in legislative policies for gender equality at the international level. However, the economic crisis has led to a growth in inequality, which has revealed the weaknesses of the adopted instruments. Despite the large amount of legislation in this area, the social reality has not changed at all, even experiencing a setback over the past few years. This situation was exposed in our country by a report issued in 2015 by the UN Committee on the Elimination of Discrimination against Women (CEDAW). This report showed the negative effects of the economic crisis and austerity policies on women, even in a context necessitating increased efforts towards women's rights. Therefore, it is imperative that the concept of gender mainstreaming and the adoption of instruments of "hard law" be revisited. The goal should be to achieve gender justice based on three elements—distribution, identity, and representation—and a real parity democracy.
\end{abstract}

Keywords: equality; gender mainstreaming; hard law; justice; economic crisis; parity democracy

\section{Introduction}

In Madrid on 12 May 2009, the Committee of Ministers of the Council of Europe, in the Declaration "Making Gender Equality a Reality", highlighted that "the legal status of women had improved over time, but that 20 years after, its Declaration on equality of women and men (Council of Europe, 1988), bridging the gap between gender equality in fact and in laws is still a challenge for its member states." However, that gap has grown in recent years in Europe: "The European Economic Recovery Plan" does not mention the concepts of "gender", "equality" or "women", despite the discrepancies of gender for women and men in the crisis. The recommendations of the European Council to Spain in 2011 and 2012 to meet the agreed EU objectives included fiscal consolidation and public expenditure control (e.g., labor and pension reform, tax increases, reductions in the provision of public services and a greater flexibility for companies). Gender mainstreaming was not included in the national reform programs and the European Council recommendations to Spain in 2011 and 2012, neither in the design of reforms, nor in the implementation of austerity measures.

This decline has been more than evident in Spain, as stated by the report made by the United Nations Committee on the Elimination of Discrimination against Women on 24 July 2015, regardless of the efforts made by Spanish legislators in the implementation of the Convention on the Elimination of All Forms of Discrimination against Women, 1979 (CEDAW) recognized in this report. It was also pointed out that the economic and financial crisis and the austerity measures implemented in 2008 have had negative effects on all spheres of women's lives. The UN Committee insisted that it is precisely at a time of economic crisis and fiscal constraint that special efforts are necessary to guarantee the rights of women, giving priority to those who are in situations of greater vulnerability. These same effects have been revealed, worldwide, by the latest report made by UN Women ([1], p. 37), which in practice means an "indirect discrimination" i.e., they have adopted some seemingly neutral policies, which greatly impact the disadvantages faced by women. 
More specifically, the Report of the CEDAW Committee draws attention to a number of negative elements of the policies of gender equality in Spain in recent years:

(1) The elimination of the Ministry of Gender Equality and the replacement of the Women's Institute by the Institute of Women and Equal Opportunities; the absence of a consistent strategy on gender equality at the state level and an appropriate coordination between the central government and the Autonomous Regions. There are also some temporary measures missing, such as short-term goals and quotas. Both of which are aimed at correcting the inequality in those areas where women are underrepresented or disadvantaged.

(2) The persistence of traditional attitudes and stereotypes regarding the roles and responsibilities of women and men in the family and in society. The Committee emphasizes that the roots of gender-based violence are concealed in many of these stereotypes and they insist on the lack of positive images in the media of women from ethnic minorities, Roma, migrants and women with disabilities. Consequently, they urge Spain to implement a comprehensive plan against stereotypes, which is based on clear and specific educational programs, as well as more effective awareness campaigns.

(3) The prevalence of violence against women and its effect on children. In the report, they also criticize the deterioration of support services for battered women, in addition to the fact that laws have not yet been revised. Moreover, there is a lack of training of judges and officials for cautiously implementing restraining and custody measures.

(4) The absence of a comprehensive law against human trafficking as well as a full/complete approach to the phenomenon of prostitution.

(5) The low participation of women in public and political life, particularly in decision-making positions in the Autonomous Regions, in the diplomatic service and in the judicial branch.

(6) The absence of an appropriate education in sexual and reproductive health after the removal of the subject "Education for Citizenship and Human Rights" in the Spanish educational system.

(7) The disproportionate impact of austerity policies in the workplace, which have already led to an increase in female unemployment, the impact of the wage gap between women and men and the precariousness of the jobs they occupy.

(8) The exclusion of immigrants in an irregular situation from the universal healthcare system has had a disproportionate impact on women's health, particularly in the sexual and reproductive fields.

(9) The vulnerable situation of women who suffer intersectional discrimination, especially Roma, migrant, elderly and disabled women.

(10) The non-implementation of a gender perspective in the regulation of asylum, so as to take into account the special vulnerability of women who are persecuted in their countries due to gender reasons.

(11) Court decisions that continue to attribute custody of children to parents who have been accused of domestic violence.

Many of the weaknesses identified by the UN Committee agree with the diagnosis that the European Commission made in 2010 when they presented the "Strategy for Equality between Women and Men 2010-2015“. They distinguished five priority areas where there was still inequality in the European countries: equal economic independence, equal pay for equal work and work of equal value, equality in decision-making, ending gender-based violence and equality in external actions. These objectives are difficult to achieve if we consider "the decline of European commitments to gender equality due to other economic priorities that are considered more important" ([2], p. 16)

The negative report of the United Nations unveils two interrelated issues: (1) The weaknesses of most of the equality policies adopted in Spain, specifically the legislative instruments; and (2) The survival of some social, political, legal, economic and cultural patterns which extend this patriarchal order. Furthermore, these patterns are reinforced, as occurred in Spain, with the combination of an economic crisis and a center-right government. Therefore, it is advisable to critically analyze the 
appropriateness of these legislative gender equality policies adopted in Spain within the last decade and to outline their strengths and weaknesses. In this study, we aim to set out a roadmap to consolidate a true parity democracy in which gender justice is guaranteed. The conclusions are suggested from the point of view of the democratic theory, rendering them equally applicable to any country that assumes equality of women and men to be one of the foundations of its political character. To do so, we will analyze what kind of legislative policies have been adopted in Spain over the last decade, how they were adapted in practice to gender mainstreaming, and the weaknesses of these policies exposed by the current economic crisis. The concept of gender mainstreaming is very relevant to analyze how public authorities have broken the promises of equality in a time of crisis. In fact, the economic and political efforts to introduce a gender prospective in all areas have not only been at a standstill but have been reduced over the past few years. The economic crisis effects on equality thus show that the more efficient instrument for fighting inequality and the only way to overcome the negative effects of austerity measures is gender mainstreaming.

\section{The Dual Strategy of the Spanish Legislative Policies on Gender Equality: Positive Actions and Gender Mainstreaming}

\subsection{The Spanish Progress in Gender Equality}

All the Spanish legislative policies on gender equality, clearly inspired by the European Union law and international law, rely primarily on the use of two tools: "positive actions" and "gender mainstreaming". The progress of gender equality within the last decade has been possible thanks to the boost of certain governments and also due to the impact of $t$ European Union policies. Although the social and economic situation reveals, the persistence of inequalities between men and women, and although the policy development in this area has been very different in various other countries, there is no doubt that the commitment of the European institutions has been essential in the development of policy instruments and public policies aimed at eliminating discrimination against women. As the European Commission acknowledged when adopting the Strategy for Equality between Women and Men 2010-2015, “The European Union's achievements in fostering equality between women and men have helped to change the lives of many European citizens for the better and provide the foundation on which we now have to build a genuinely gender-equal society." However, the European Commission itself assumed the persistence of discrimination in the workplace or in positions of responsibility, as well as the continuation of roles and stereotypes assigned to the sexes by stating areas of action for those five years.

Spain has undoubtedly been one of the leading progressive countries in this area. Since the adoption of the Constitution of 1978, we have witnessed a radical evolution of the legal system, public policies and society itself. In regards to this change, the equality organizations created in the ' 80 s were decisive. Furthermore, in 1983, the creation of the Spanish Institute for Women's Affairs at the state level marked a turning point in gender policies in Spain. That kind of organization would later be imitated in most of the Autonomous Regions. This state model was also reproduced in the tools used to develop equality policies, such as the multi-year action plans that the Spanish Institute for Women's Affairs have been approving since the late 80s. In the following decade, the inspiration for regional plans was the European Union; gender equality policies were thus institutionalized.

Nevertheless, the strongest legislative initiatives are very recent. It was in the 8th legislature with the first government made up of an equal number of women and men led by Jose Luis Rodriguez Zapatero, that they approved two laws that can be considered complementary and which have become an international model: The Spanish Organic Act 1/2004 dated 28 December on Integrated Protection Measures against Gender Violence; and the Spanish Organic Act 3/2007 on Substantive Equality between Women and Men. In addition, The Act 39/2006 dated 14 December for the Promotion of Personal Autonomy and Attention for Persons in Situations of Dependency, the so-called "Dependency Law", was presented as a pillar of the Spanish welfare state as it assigned some state responsibility to the provision of care for dependent people within the Spanish context for a sector which has traditionally been the 
responsibility of women. We can currently see that the virtual paralysis of the implementation of this law within recent years is the most obvious sacrifice of equality policies in favor of the dominant economic interests.

In order to create these two instruments, the Spanish legislator used the guidelines which had been previously set by international law and especially by EU law ([2], pp. 23-24). Therefore, the Preamble of the Organic Act 1/2004 states that:

This Act will take up the recommendations of international bodies on providing a global response to the violence exercised against women. We can quote in this regard the 1979 Convention on the elimination of all forms of discrimination against women; the United National Declaration on eradicating violence against women, issued in December 1993 by the General Assembly; the resolutions of the last World Conference on Women held in Beijing in September 1995; resolution WHA49.25 of the World Health Assembly, issued by the WHO in 1996, declaring violence a priority public health problem; the European Parliament report of July 1997; the resolution of the United Nations Human Rights Commission of 1997; and the declaration of 1999 as the European Year for Action to Combat Violence against Women, among others. Just recently, Decision 803/2004/EC of the European Parliament approved a community program of action (2004-2008) to prevent and fight violence against children, young people and women and protect its victims and groups at risk (the Daphne II program), which sets out the stance and strategy on this issue of the representatives of Union citizens.

On the other hand, the Organic Act 3/2007 starts with the recognition of equality as a fundamental principle in the European Union: "Since the entry into force of the Treaty of Amsterdam on 1 May 1999, equality between women and men and the elimination of inequalities between them constitute an objective that must be integrated into all the policies and actions undertaken by the Union and its members." Specifically, the Act incorporates two Directives on equal treatment into the Spanish legal system: the 2002/73/EC amending the Directive 76/207/EEC on the principle of equal treatment between men and women regarding the access to employment, vocational training and promotion, in addition to working conditions; and the Directive 2004/113/EC which implements the principle of equal treatment between men and women with regards to access to goods and services and their supply.

\subsection{The Commitment to Gender Equality of Regional Institutions}

The legislative instruments and policies implemented by the central government are complemented by the advancements made by the Autonomous Regions ([3], pp. 57-58). With different levels of political commitment, the Regional Parliaments, in some cases even before the state, have approved laws on gender equality and against gender violence. All this, together with the consolidation of institutions-such as women's institutes, policies implementation and the different equality plans, for example-first focused on the promotion of "equality of opportunities". The commitment to gender equality of regional institutions was even reflected in the statutory reforms from 2006. The principle has been incorporated into the basic institutional norm of some Autonomous Regions.

Here we can briefly distinguish between two types of regional laws ([4], p. 99): (1) laws which placed the issue of equality in the context of equal opportunities, and as a matter of equality "between" women's and men's rights. These laws adopted a liberal analysis of inequality: they did not influence the causes of it but the difficulties of women to fit in the framework of the existing rights; and (2) Laws that present a more complex analysis of gender inequality beyond the concept of "equal opportunities" and introduce the concept of "equality of women and men".

All these legislative instruments, clearly inspired by European Union and international law, rely primarily on the use of two tools: "positive actions" and "gender mainstreaming". The Preamble of the Constitutional Act 3/2007 clearly states that: "The primary novelty of this Act lies, in any event, in the prevention of discriminatory behavior and the provisions for active policies to translate the 
principle of equality into effective practice. Such an option necessarily involves an extension of the principle of equality to the areas of the legal system regulating social, cultural and artistic reality, where inequality may be generated or perpetuated. Consequently, the cross-sectional dimension of equality, a conceit that distinguishes modern anti-discriminatory law, is the fundamental principle of the present text." The concept of gender mainstreaming had been previously used in some Equality Plans and in some regional laws like Navarra 32/2002, which promotes equal opportunities between women and men, and the Basque 4/2005 for equality between women and men. Subsequently, they have been incorporated in some of the statutory reforms since 2006. For example, Article 41.2 of the Catalan Statute provides that "public authorities must ensure gender mainstreaming in all public policies to ensure real and effective equality and parity between women and men".

According to this, Article 5 of the Organic Act 3/2007 includes the principle of mainstreaming gender equality: "The principle of equal treatment and opportunities for women and men will cross-sectionally inform the action taken by all public authorities. The central, regional and local governments will actively mainstream the principle in the adoption and implementation of their legislative provisions, definition and budgeting in all areas of public policy and performance of all their activities as a whole." On the other hand, Article 11 gives legitimacy to positive actions: "In order to ensure the effectiveness of the constitutional right to equality, public authorities will adopt specific measures favoring women to correct situations of obvious de facto inequality with respect to men. Such measures, which will be applicable while the situations subsist, must be reasonable and proportional to the objective pursued in each case."

The regional legislation has also adopted this "dual strategy", as it was defined by the Valencia Act 9/2003, dated 2 April for Equality between Women and Men: the complementary use of positive actions and the ones related to gender mainstreaming (Article 2) [5]. The most comprehensive regulations on the subject, before the state legislature approved in 2007, was made by the Basque Parliament by Act 4/2005 dated February, 18th for the Equality of Women and Men, which starts with "the systematic consideration of different situations, conditions, aspirations and needs of women and men, incorporating objectives and specific actions designed to eliminate inequalities and to promote equality in all policies and actions at any level and in all planning stages, implementation and evaluation".

All this legislation has literally reproduced the concepts and definitions already mentioned in the European Union law in this area. Therefore, for example, the differentiation between "direct discrimination" and "indirect discrimination" or the distinction between "sexual harassment" and "gender harassment" already consolidated in Europe is also included.

As an example of a basic institutional rule of an Autonomous Region in which it is included as one of the articulating principles of gender equality, we can mention the Statute of Autonomy for Andalusia, after the reform carried out by the Organic Law 2/2007 dated March 19th. Its Article 10.2 includes, among its basic objectives of the EU, "an effective equality of men and women from Andalusia promoting parity democracy and the full integration of women in social life, overcoming any labor, cultural, economic, political or social discrimination." Article 15 provides that "equal opportunities between men and women in all areas" must be guaranteed. Moreover, explicitly, Article 16 recognizes the right of women "to a comprehensive protection against gender violence, including preventive measures, aid measures and government support".

Immediately after entering into force the statutory reform, the Andalusia Parliament adopted the Law 12/2007 dated November 26th, to promote gender equality in Andalusia. The preamble of the law makes clear the location of this law in the context of European Union law:

In the context of the European Union there have been numerous directives, recommendations, resolutions and decisions concerning equal treatment and opportunities for women and men, and they have also developed various community action programs for equal opportunities. The Amsterdam Treaty approved by the European Council in Amsterdam on 16 and 17 June 1997, in its amendments to the Treaty of Rome dated 25 March 1957, established within the European Community, includes in its Article 2 a 
specific reference to equality between men and women as a mission of the Community. Likewise, in paragraph 2 of Article 3 the objectives of eliminating inequalities between men and women and promoting equality are incorporated; these objectives must inspire all Community actions and policies. We also have to point out that articles 20 and 21 of the Charter of Fundamental Rights of the European Union establish both the principle of equality before the law and the prohibition of discrimination. Moreover, the Charter contains a specific article, number 23, dedicated to equality between women and men and positive actions as compatible measures to equal treatment. There are also some specific Community rules, such as Directive 2002/73/EC of the European Parliament and of the Council dated 24 September 2002 on the application of the principle of equal treatment between men and women regarding the access to employment, vocational training and promotion, and working conditions and Directive 2004/113/EC dated 13 December 2004 which establishes the principle of equal treatment for men and women applied to the access to goods, services and supply and Directive 2006/54/EC of the European Parliament and of the Council dated 5 July 2006 on implementing the principle of equal opportunities and equal treatment for men and women in matters of employment and occupation."

Article 5 of the Andalusia Law opts for the application of the principle of gender mainstreaming: "The government will enhance that the perspective of gender equality is present in the preparation, implementation and monitoring of regulatory arrangements, policies in any kind of area, considering the priorities and needs of women and men, taking into account its impact on the specific situation of women and men in order to adapt them to eliminate the discriminatory effects and promote gender equality".

\section{The Fragility of Gender Mainstreaming}

\subsection{The Definition of Gender Mainstreaming}

In this section, the objective is to analyze how gender mainstreaming works from the Spanish experience. In general, and thinking of the systematic effects, we can distinguish four major stages in the development of equality legislation in Europe [4]: (1) liberal anti-discrimination legislation phase, in which these policies were based on the concept of equal treatment and were mainly directed to the protection of inequality in the public sector, and especially in the labor market; (2) legislation in favor of equal opportunities, focused on the workplace; (3) laws of gender mainstreaming; and (4) legislation on gender equality and intersectionality, in which women's diversity and different aspects related to it are taken into account.

Most European countries, including Spain, are located in the third phase, which in practice is incomplete and unsatisfactory. The goal would be to complete the third phase and, at minimum, enter the fourth. The economic crisis has undoubtedly affected the singular application of gender mainstreaming and, in general, all Spanish equality policies: "Firstly, many of these equality laws, which have been recently adopted, have a very limited and partial regulatory development $(\ldots)$ Furthermore, this context of progressive dismantling of the welfare state has had its effect on one of the key elements for the development of mainstreaming which are equality institutions" ([6], p. 136).

Many of the weaknesses of the policies of gender equality in our country come from the misapplication of the principle on which they are based, i.e., the principle of gender mainstreaming. In most cases, its introduction has been merely rhetorical. Moreover, there is no consensus about the meaning of the principle and its application. On the contrary, what we find are multiple options adapted to the respective national contexts. In this sense, what you have is a mainstreaming " $a$ la carte" ([6], p. 49).

Even the translation of the word into Spanish reveals its poor performance. Mainstreaming is not just a transversal approach. That is, the aim of this principle is not only that gender equality is present in all public policies, but also that it is "the main way". This was quite clear in point IV of 
the Platform for Action adopted at the Fourth World Conference on Women held in Beijing in 1995: "to promote an active and visible policy of mainstreaming a gender perspective in all policies and programs." This requires that the concept of gender, as an analytical tool, is present in all stages of the development of these policies — design, implementation, and evaluation-and that all actors and actresses properly trained in the field were involved. And the whole process should be understood as an essential and mandatory part, and not as a mere recommendation to be left in the hands of political wills. As Juana Gil ([7], p. 17) states, "in order to achieve the objectives of gender mainstreaming, some cathartic changes, which are not achievable immediately, are needed: a deep revision of management policies and a serious commitment with an effective equality gender training for all staff involved in its implementation."

One of the most comprehensive definitions of gender mainstreaming is provided by the group of experts of the Council of Europe ([8], p. 26) ${ }^{1}$, for which "Gender mainstreaming is the organization (reorganization), development, implementation and evaluation of policy processes, so that a gender equality perspective is incorporated in all policies at all levels and to all the activities of the actor ordinarily involved in the policy processes at stake."

This definition implies considering five key elements ([15], p. 7): (1) A change in the concept of gender equality, more encompassing than the existing, so that we do not only consider formal equality, but also material equality and how gender affects the opportunities of women and men as well as relations between both; (2) The incorporation of a gender perspective in the predominant political agenda; (3) The inclusion and participation of women in institutions and decision-making processes; (4) The priority given to gender equality policies and to those which are particularly relevant for women; (5) A change in the institutional and organizational culture, which should affect political process, political mechanisms and political actors: (a) A change in the political process means that it "is rebuilt so that the actors usually involved take into account a gender perspective and the goal of gender equality is achieved"; (b) A change in the political mechanisms requires two conditions: (1) A horizontal cooperation on gender issues among all areas, departments and political levels (national, regional, local); (2) The use of the appropriate tools and techniques to integrate the gender variable in every policy to monitor and evaluate them from a gender perspective; (c) A change in the actors involved in the political process requires expanding these to include not only ordinary actors of politics and administration, but also experts in gender equality and civil society.

Therefore, gender mainstreaming "includes training and awareness of politicians and technicians at public administrations, generating analytical and informative tools, reviewing policy goals, bringing in experts, feminist movement and civil society, transforming the organizational culture, expressing leadership and public commitment to equality, and creating opportunities for cooperation to overcome a cross-sectorial approach to gender, among other issues. It is, therefore, a strategy of transformation in depth of the values and routines of the public administrations which more or less explicitly questions and challenges the values and hegemonic priorities." ([16], p. 72)

The strategy of mainstreaming should be developed in four phases ([6], pp. 39-43): (1) Mandate: at this stage we would understand the mainstreaming in a rhetorical or declarative sense; (2) Tools or development of specific instruments whose object facilitates the review of all policies from a gender perspective; (3) Results or findings of specific changes in sectorial policies; and (4) Impact or existence of changes in the situation of men and women as a result of the above results.

\subsection{The Implementation of Gender Mainstreaming in Spain}

The analysis of the implementation of gender mainstreaming by the Spanish authorities shows that, in most cases, it has been limited to a formal or procedural dimension, without progress in the substantive dimension. This would mean "changes in the way of legislating and building public

1 About the concept of gender mainstreaming, see [9-14]. 
policies that allow greater democracy and greater empowerment of women (...), a renewal in the form and content of citizenship" ([4], p. 94). We cannot forget that gender mainstreaming can end up being an empty signifier that can accommodate multiple avenues of action that are understood by gender equality policies yet which are not necessarily transformative ([6], p. 50).

That is, mainstreaming must involve not just a mere introduction of a phase in the process of drafting legislation or any public policy, but the integration of the objective of equality between women and men in real contexts and in each axis through which the policies are implemented. Therefore, the principle should be present in all phases of public policies: design, implementation, periodic evaluation and update. Furthermore, the correct application thereof would require a continuous dialog with businesses, social partners and the institutions responsible for equality and civil society representatives. Both requirements must connect with the demands of these legislative processes, which cannot be contemplated as isolated acts of parliament but as a sum of all actions carried from the developmental phase to the implementation control and the evaluation of results. All this also requires "developing tools to promote the generation and transmission of knowledge on inequalities and how to take them into account in policy making" ([6], p. 17). To this end, some different organizations were created in Spain, at the state and regional levels, such as Equality Units or Equality Observatories.

In this way, for example, all draft laws and general regulations made by the government and all the legislative proposals should incorporate a report on gender impact, specifically something that in the first case exists in the Spanish legal system but in practice it is overlooked or poorly executed. Article 19 of the Organic Act 3/2007 requires that there is a gender report incorporated into all projects of general regulations and plans of special economic, social, cultural and artistic relevance that are subject to the approval of Council of Ministers, as a matter of extension of the provisions made in the Act 30/2003 of October 13. This act incorporated gender impact valuation in regulations prepared by the Government. Subsequently, on 3 July 2009, the Council of Ministers approved the Royal Decree 1083/2009, where the Memory of the Regulatory Impact Analysis is regulated [17]. That report should be the key, not only in project preparation, but also in its implementation and the subsequent evaluation of the results. Of course, it should not be limited to a single document incorporated in the relevant files, but should "have a profound impact on the process of developing the regulations" ([7], p. 79).

The report should be particularly relevant in certain areas such as budgets, as this is the main instrument which defines the priorities of a government. Therefore, it would be desirable to create the corresponding Commission in the Parliament-as exists, for example, in Andalusia-responsible not just for ensuring that requirement in the creation of the law, but also, and especially, in its development and implementation. At a time when the economic situation increases the feminization of poverty and hinders the full exercise of citizenship for women, it is more necessary than ever to consider their situation in order to adopt any kind of policies-especially those of social and economic nature-and, in this way, to value the intersectional discrimination that affects most of them. Intersectional discrimination theory suggests that-and seeks to examine how-various biological, social and cultural categories such as gender, race, class, ability, sexual orientation, religion, caste, age, and other axes of identity interact on multiple and often simultaneous levels.

In order to ensure such a gender perspective, it is necessary to create gender units in all departments of the public administration, as well as an Interdepartmental Commission for Equality of Women and Men, in line with the one in the Andalusian Autonomous Region. Furthermore, all these processes should include the participation of women. However, in practice, this requirement has been raised ([6], pp. 49-50), "as a purely technical procedure, in which the usual political actors receive all the attention. This does not only move the feminist movement to the background, but sometimes also experts in gender no longer enjoy the privileged role that their knowledge gave them. In fact, Mainstreaming has many times become an administrative procedure which is performed to cover the record." Therefore, it has a rather depoliticizing effect whereby instead of generating a debate on inequalities and their impact on the usual policies, it eventually leads to a suspiciously consensual and lacking in conflict review." In this regard, we have to remember that in recent years in some 
Autonomous Regions, they have suppressed the bodies set up specifically to develop equality policies, a measure that has been justified because of the context of economic and financial crisis, and because of the need to rationalize the operation and size of the public sector.

Furthermore, gender mainstreaming should be present in all branches of the government, not just the legislative branch ([7], p. 66). It should also be shown in the work of the executive branch and therefore in the whole public sector and especially in the performance of the judicial branch. In this last sector, it should be done from two perspectives: (a) judges should ensure that the rules integrate a gender perspective in its content; (b) judges should also control that this measure is carried out in the proceedings, both legislatively and administratively, and that the formal requirement of the gender impact report is successfully included.

As a consequence, it would be essential to ensure the participation of women in the definition, implementation and evaluation of gender equality policies, as well as the participation of gender experts in the development of the strategy of mainstreaming. As a result, the institutions working on the participation of women's groups should be consolidated from the point of view of their legal status and especially of their jurisdiction, and the permanence and continuity of the institutions responsible for these policies should be ensured. As it is shown in recent studies, "the gap between the academic elucidations and the administrative proceeding, the limited presence of the feminist movement in the decision-making sector, and the weaknesses of the administrative structures of equality, are drilling all the actors in favor of gender equality and their capacity to decide on structural issues of inequality that are beyond the 'specific needs of women' which have already been considered" ([18], p. 181).

The principle of gender mainstreaming must be the foundation of all public policies and, accordingly, it is necessary to continue the implementation of positive actions in certain areas where the inequality of women is still evident. This is the case, for example, of the political discipline, in which the progress made in recent years has been possible due to the obligation to respect the principle of a balanced representation of women and men in public bodies and institutions, as well as in the lists of candidates for the elections. Next to this field, we should not forget the economic discipline. In this sense, we should not forget the failure of the European Union in establishing mandatory quotas in the economic sector.

From this point of view, there is a clear connection between gender mainstreaming and parity democracy due to the fact that, in order to change the direction of public policies, it is necessary for women and men's participation to be balanced. Act 3/2007 specifically states that a balanced presence means "the presence of women and men so that, in all that relates to the people of each sex does not exceed $60 \%$ or be less than $40 \%$ " (1st additional regulation). According to this, there was a reform of the Organic Act 5/1985 of June 19th, on the General Electoral System, by which the lists of candidates must have a balanced composition of men and women, so as to have at least $40 \%$ representation of each of the sexes.

\section{The Weaknesses of Equality Laws in Spain}

\subsection{The Equality "Paralyzed"}

The negative consequences that the economic crisis and austerity measures have produced in Spanish equality policies have revealed the weaknesses of the legal instruments used thus far. My reflection will focus on Spanish equality laws. Despite the ambition of most of the laws approved by both the state and the Autonomous Regions, their viability has been compromised in a period in which budgetary stability has had more weight than social policies. In fact, in 2011, the Spanish Constitution was amended in order to include the principle of budgetary stability, which is obviously a condition for the development and implementation of social and equality policies. Somehow, the political and institutional crisis, both caused by the economic one, have revealed the inadequacy of some legal tools that have tried to reach a new reality based on old paradigms. That is, it has been shown that having well-meaning laws is not enough to transform a reality that responds to "a strong 
and elusive patriarchal system, disguised of legal formalism, which lies in the socio-cultural context and in stereotypes inherited and transferred from generation to generation; or even in traditional, historical, religious or cultural attitudes used as a pretext to justify the violation of women's right to equality before the law." ([7], p. 13). Therefore, "the laws, which establish equal rights for men and women, offer a very important basis in order to demand and achieve equality in practice. But equality before the law is not enough to guarantee the full enjoyment of rights by women: it is also necessary to deal with the inequalities in terms of power, structural and social policies and discriminatory practices." ([1], p. 24).

In addition, it must be mentioned that there have been significant changes in recent years in the legislative dimension:

"So, on the one hand, the approval of various equality laws in the regional context has been paralyzed and, on the other hand, the protection of pregnant women and the right to life has been included on the political agenda. These topics have been incorporated into regulations, which represent a paradigm in relation to the preceding laws, since they focus on the role of women as mothers, limiting their ability to make decisions regarding abortion and completely obviating the transformation of gender roles. Besides, the central government initiated a reform process of the abortion law in order to significantly restrict this right" ([6], p. 38).

On the other hand, many of the objectives that arose in equality laws have been paralyzed:

"The proposal for a law on equal treatment and non-discrimination on multiple inequalities, which was presented in January 2011 to complete the transposition of the EU legislation on equality, has been left out of the political agenda as it is now focused on austerity measures. Similarly, the extension of paternity leave from two to four weeks to come into force in 2011 suggested by Zapatero in the Act 9/2009 has been stuck on the grounds of the economic crisis. Labor rights and the Act on the Promotion of Personal Autonomy and Care for Dependent People have also been cut in different ways, to the detriment of equality. The possibility to enjoy the rights to combine work and family life has been reduced by Act 3/2012 of July 6th, on the Labor Reform" ( [2], p. 28).

We can therefore summarize the deficiency of the legislation in three key areas, as outlined in the following.

\subsection{The Predominance of Soft Law}

There is a predominance of provisions in Spanish equality laws responding to the technique "soft law". As Ana Rubio explained ([19], pp. 50-51), soft law is characterized because of its non-binding character and because of its difficult integration in the traditional theory of law. It would be adjusted to what Bobbio called "promotional role of law":

"This is a law whose purpose is to propose, not to impose certain behaviors or practices; that is, a right that tries to seek the voluntary adherence of the varied regulatory subjects to whom it is addressed due to its nature (...). The value and functionality of the soft law lies in its ability to generate new forms of cooperation, participation and integration in contexts and relationships in which various subjects, interests and levels of regulation converge; in addition, they are also opened to strong uncertainties and changes to which the administration has difficulties of legitimacy to regulate them."

There are various types of soft law ([19], p. 59): (a) public soft law ad intra whose aim is addressed to the self-organization of the administration; (b) private soft law, whose purpose is self-regulation; (c) private-public soft law in which public nature is mixed with some elements related to contractual principles between individuals. Furthermore, "within each of these forms of soft law, we can find 
unilateral and conventional forms established through different negotiation processes. The legal effects of each of these modalities depend on the technique used for its incorporation."

In the Spanish practice, the prevalence of this type of legislative measure implies that most of the instruments provided do not have a binding nature nor an appropriate sanction in the event of unfulfillment. Rather, they merely establish some recommendations; open regulatory processes that will have to be later supplemented by public or private powers, or establish principles, which will only be realized through political action or collaboration with social and economic agents. The prevalence of this type of instrument does not help as its application and development depend on the political will of each moment. Consequently, they run the risk of being settled in second place when there are other priorities in the government. Moreover, it is a kind of legislative instrument that requires some social actors who were "sensitized" on the matter and who understand that their participation in the effectiveness of the regulation will bring them and the society as a whole some benefits. This specific sensitivity of social and economic actors and the resulting responsibility, are very far from being achieved, especially if we consider that the dominant structures of our societies still respond to a patriarchal order.

With regards to this, I agree with the conclusions of Ana Rubio ([19], p. 68):

"Using soft law or hard law depending on the case has helped the State to carry out an important process of action on gender equality with legitimacy in specific contexts which do not always find constitutional support. We have used this technique within all its limits in order to legitimize the actions of public authorities, without the responsibility of a regulation integrated in the hierarchic system, as they displace the capacity of private actors to decide and to regulate. If the subjects mentioned in the law had taken the soft law as a guide to take action, as it has happened in other contexts (energy context, fiscal accounting in companies, Building Code), its normative and social effectiveness would have been guaranteed."

Therefore, the obstacles seem to find their roots in the two factors outlined below.

\subsection{The Formal Conception of Equality}

Most of the measures designed to correct or prevent discrimination against women in various spheres of social life have started from a formal conception of equality, of a liberal type, in which the reference subject has always been the man. This is a grave problem in Spanish policies on gender equality. As a consequence, equal opportunity policies and specific measures to correct particular situations, in which they used some tools that have led to the consideration of women as a collective or a social group, prevailed. However, as legal feminism reveals, the key would be based on the consideration of women as "half" of the citizens and on the structural causes underlying discrimination. That is, the law should start from the position of subordination in which women are in a political, legal, economic and cultural order due to the features of the current patriarchy. This happens because of the power structures between men and women. Therefore, the other dichotomous pairs that articulate our societies—male/female, public/private, provider/caregiver, reason/emotion—thereby legitimizing different social roles for men and women, must be reviewed.

CEDAW defines discrimination as "any distinction, exclusion or restriction made on the basis of sex which has the purpose or effect of impairing or nullifying the recognition, enjoyment or exercise by women, irrespective of their marital status, on a basis of equality of men and women, of human rights and fundamental freedoms in the political, economic, social, cultural, civil or any other field." As we can see, "the definition does not say that women should be treated as men in order to eliminate discrimination. On the contrary (...) if you give a woman the same treatment as a man and this treatment leaves her in a lower position, this treatment itself is discriminatory despite the fact that its goal was equality" ([7], p. 37). 
In this structural dimension of gender inequality, anti-discrimination instruments should take into account that women are often victims of different factors that place them in situations of disadvantage, forcing us to give legal responses to those specific cases of intersectional discrimination. Only in such a way, for example, is it possible to successfully eradicate the different types of violence-physical, psychological, sexual, economic, symbolic_against women.

\subsection{The Man as the Prototype of a Subject}

Similar to the previous idea, our legal systems are still built on the bases of a male reference as the prototype of a subject. That is, the subject of rights-the citizen-is still the man, the individual who also meets the specific requirements of patriarchy. Public and private spaces, and the relations between them, are organized according to the subject model, which places women at a devalued position or, at best, in an extremely fragile position. In democratic states we have not revised yet, for example, the whole theory of human rights which responds to the model of the male subject: heterosexual, proprietor and white. Moreover, labor relations respond to the parameters that divide tasks between the man as a "supplier" and woman as a "caregiver". This division affects our entire production model and our economic system, in which women suffer conditions that have become even more precarious in these times of economic crisis. The Spanish constitutional system responds to this paradigm.

This citizenship has been built from the dominant paradigm: the patriarchal perspective of capital. Thus, the subject who is inserted in the constitutional regime is a subject fully available to the interests of the capital and has full autonomy and freedom to reach an agreement ([20], p. 23). Even the social state model introduced in the late-20th century in countries like Spain relied on "a model of productive work prototypically masculine" ([4], p. 88) and on the role of women as caregivers. That is, a social state where certain benefits linked to the work of care-for example, with children, the sick and/or elderly people-have been kept in the family and supported, where appropriate, with some economic support by the state. This aid has progressively disappeared because of the dismantling of equality policies in these years of crisis, which has negatively impacted the position of women.

Consequently, it is urgent not only to transform, socially and culturally, male and female subjectivities and the relationships between them, but also the construction of legal subjects. As a consequence, the liberal concept of citizenship should be reviewed and, therefore, the concept of ownership and content of rights and freedoms. For example, with the proposed changes, it would be possible to proclaim and effectively guarantee the right of women to a life free of violence. Otherwise, we will still be prisoners of the "eternal" dilemma, "the (im)possibility of the fact that an inherently gendered State contributes to promote equality" ([6], p. 11).

\section{Conclusions: Parity and Gender Justice}

The Spanish experience of recent years exposes the weaknesses and the challenges in gender equality policies. We can individualize the following objectives for a constitutional system that takes seriously gender equality:

(1) In a constitutional regime, in order to prevent what we have reported in the previous pages-namely, that equality policies depend on economic factors and political wills-it is necessary that the principle of parity democracy be constitutionalized. Only in this way will it be possible to meet the challenge that was settled the 1992 Athens Conference: "Women represent more than half of the population. Equality requires parity in the representation and administration of Nations. Women represent half the potential talent and skills of humanity and their under-representation in decision-making posts is a loss for society as a whole." Gender mainstreaming is the key to achieving real parity democracy because it involves two goals: (a) the principle of equal treatment and opportunities for women and men will cross-sectionally inform the action taken by all public authorities; (b) The inclusion and participation of women in institutions and decision-making processes. 
(2) The aim of equality does not only have a quantitative dimension: "parity is not about numbers. It is, however, a qualitative condition, the condition of being a peer, to be on par at the same level with others, to interact with them on conditions of equality" ([21], p. 196). Thus, it does not only mean that women and men are equal in the access to power and its exercise, but also that we have to review the status of citizenship itself. This is to "articulate gender as a theoretical category, as the analytical tool through which the division of social experience along gender lines tends to give men and women different conceptions of themselves, their activities and beliefs, and the world around them" ([22], p. 29)

That is, the key to talking about parity democracy is not so much sex or gender, but rather the system of power that builds male and female subjectivities, the relations between them, as well as the opportunities of both for the exercise of their fundamental rights. From this point of view, parity democracy implies influence in the heart of the constitutional system, as it assumes reviewing its two main areas: power and citizenship. Therefore, it does not mean an attack on the liberal representative model, but rather a democratic development of structures that were created to respond to the interests of the white, male, and heterosexual man and proprietor. This implies a critical look at liberal democracy, as feminism has been doing for three centuries, or, in terms of a pact that "first excluded them de jure and then has maintained them excluded de facto" ([23], p. 45). An agreement, which is based on a supposedly hidden and hardly universal and abstract logic that says that there has always existed a privileged half, the male, in comparison with the female half, held in conditions of subordination [24]. Overcoming these obstacles means returning women who had their own voice to the place from which they were excluded, i.e., the "original pact" with the constituent assembly ([25], p. 39). Only in this way could it be possible to achieve "parity of participation, that is, for each and every one to be able to participate "as full partners in social interaction" ([21], p. 225).

(3) The qualitative dimension of parity democracy needs to ensure not only the presence of women in the exercise of power, but also their ability to influence political decision-making processes. As rightly pointed out by the latest report by UN Women ([1], p. 52), a key objective to achieving real equality is to strengthen the power of action, the voice and participation of women. For this purpose, not just women but also men committed to a "feminist agenda" are needed; that is, breaking the constraints of this sex/gender system, which urgently requires changes to institutions, economic policies or relations between public and private sectors. Therefore, the commitment to a "gender agenda" implies "more ambitious and crossed aims: restructuring both state-public space (political decisions), and the public and non-state space (the market), even reaching the domestic field" ([26], p. 89). All this means taking gender mainstreaming seriously or "prioritizing the elimination of discrimination caused by a systemic structure which is just the sex-gender" ([27], p. 247). We should note that "modifying the agenda necessarily means something more complex, as more and more decisions are made outside the democratic public spaces, where gender mainstreaming has been spread. In this way, it seems inevitable that if you want to cause a change in the agenda, a top priority should be to restore the democratic decision-making spaces, where you give an explanation to the citizens and public priorities are chosen collectively" ([16], p. 90).

(4) Parity should be incorporated into constitutional regimes as a principle, that is, as an "optimization mandate", which should consequently govern the actions of all public branches and, therefore, impact citizenship and relationships between individuals (e.g., in the field of market or labor relations). The incorporation of this principle would force countries like Spain to continue the work started by the legislature and which has had a disparate impact in practice. The last objective would be the reworking of a social contract that still relies on the previous "sex" model, and breaking with this traditional model of citizenship. This would entail a threefold process ([4], pp. 103-4): (a) breaking the dual structure of citizenship based on the dichotomy 
of public and private spheres; and (b) articulating a model of plural and diverse citizenship; (c) moving from "ciudadanía" to "cuidadanía"2. As Nancy Fraser ([21], pp. 164-65) posits, it is necessary to establish a social state based on a model of the individual - the universal caregiver-in which "the current patterns of women's lives become the norm for everybody" so that "the sexist opposition between supplier and caregiver" would be dismantled and it would encourage men to perform this other activity too.

(5) As a result, it is necessary to consolidate a family model and productive relationships in which there is no longer a separation between the roles of the provider and caregiver, so that men and women are "supporters/caregivers in equality" ([28], p. 28). All this would have a clear impact on economic policies. In addition, we would hardly advance equality between women and men unless we work on economic structures that are perpetuating the inequalities. As it has been significantly pointed out by the latest report of UN Women, entitled "Transforming economies, realizing rights" ([1], p. 13), "to support the substantive equality, economic and social policies need to work in tandem. Typically the role of economic policies is seen primarily in terms of promoting economic growth, while social policies are supposed to address its casualties by redressing poverty and reducing inequality. But macroeconomic policies can pursue a broader set of goals, including gender equality and social justice. Conversely, well-designed social policies can enhance macroeconomic growth and post-crisis recovery through redistributive measures that increase employment, productivity and aggregate demand." We should note that today "the prevailing macroeconomic analysis obviates the complex interrelations between formal, informal and domestic economy, as well as the economic role that women and men play in these areas. This determines the effect of every policy which is framed in such an analysis, whether expansive or restrictive-and therefore it is difficult to include a gender perspective in these fields." ([13], p. 74).

For this reason, as previously mentioned, it is essential that this gender perspective be present in the Finance Act and, in general, in every economic plan approved by the government. Nevertheless, we cannot forget that in Spain in recent years there has been a significant reduction of equality policies in budgets:

"if we analyze the total variations in the state budget and in the budgets of the Autonomous Regions in the two periods before and during the crisis, we can see in the period 2002-2008 that, in every analyzed case, the budget for gender policies increased significantly reaching $57.2 \%$ statewide, whereas in the period 2009-2013 the budget decreased at all levels of the government (getting to $-34.1 \%$ for the Central Government), with the exception of Andalusia where the budget for gender policies was increased by $15.5 \%$ " ([2], p. 28).

The latest report by UN Women ([1], pp. 194-95) emphasizes the importance that such macroeconomic policies have been improving the disadvantages of women: (1) Macroeconomic policies have a direct impact on both the quantity and the quality of employment opportunities for women and men; (2) They have an effect on the responsibilities of housework and the unpaid care through their effects on employment, household income and living standards; (3) They have distributional consequences-for example, with taxes—-that affect women and men differently; (4) They affect the available resources of governments to finance social policies and social protection programs that can be used to reduce the socioeconomic disadvantages of women.

(6) It would be essential to establish an ongoing dialog between the government and civil society; between, for example, the administration and businesses, or between the representative bodies

2 Encarna Bodelón uses the term "cuidadanía" ("cuidado" more "ciudadanía", that is to say "care" more "citizenship") , similar to "ciudadanía" (citizenship) to overlight the importance of "care". 
and citizens in order to develop, implement and evaluate these policies. Moreover, in countries like Spain, in which there is a territorial decentralization of power, it would be crucial that the principle of parity was present at every territorial level and that there would be an appropriate cooperation between them. We also have to keep in mind that, on many issues, the division of power between different authorities forces them to work together. Therefore, we should develop a governance of a "cooperative federalism": "In this way, the process of learning across regions is not diminished, and the dissemination of policies and institutions also occurs. Moreover, the trend of cooperation has prevented duplication and has favored the implementation of complex policies as those related to gender violence" ([6], p. 75).

(7) The social changes pursued with the proposals mentioned above would not be possible, or in any case would have limited effectiveness, if they were not accompanied by cultural changes; that is, if parity democracy is not extended beyond the constitution and the law. The cultural sustenance of the changes that gender equality demands, is nothing more than overcoming the construction of male and female subjectivities and relations between both of them, which is marked by a hierarchical differentiation between each other, as well as the opposition between reason/emotion. As the European Commission stated in the Strategy for Equality between Women and Men 2010-2015, "the attribution to men and women of rigid gender roles can hamper individual choices and restrict the potential of both women and men. Promoting non-discriminatory gender roles in all areas of life such as education, career choices, employment and sport is thus an essential contribution towards gender equality." For instance, changing these stereotypes is at the root of the fight against violence, as the Council of Europe Convention highlighted on preventing and combating violence against women and domestic violence, adopted in 11 May 2011 in Turkey: "Parties shall take the necessary measures to promote changes in the social and cultural patterns of behavior of women and men with a view to eradicating prejudices, customs, traditions and all other practices which are based on the idea of the inferiority of women or on stereotyped roles of women and men" (Article 12).

Therefore, most of the socializing patterns that still prevail and keep educating men and women in different ways should be modified. As a result, it is important that the educational system incorporates and takes seriously the task of educating citizens to be responsible in public and in private. Consequently, gender mainstreaming should be viewed as a transversal category in the educational curriculum, and there should be other subjects that specifically explain the situation of women and men in our societies. These changes would not be possible if, in turn, we do not incorporate women as subjects of knowledge and if we do not review the scientific model that has always had a male reference. In other words, knowledge and science have always been built with androcentric parameters, and these fields have neither taken into account the experience of women nor their contributions as creative subjects. Only if we change this perspective of thought will it be possible to reach a different educational model. In addition, there must be a much stronger influence of public authorities on the other socializing factors-media, advertising - in which a great majority keep showing androcentric and patriarchal values.

As Nancy Fraser ([21], p. 31) suggests, gender justice must necessarily become three-dimensional, "incorporating the political dimension of representation alongside the economic dimension of distribution and the cultural dimension of recognition." A similar conclusion comes from UN Women ([1], p. 43) when they say that in order to achieve substantive equality, it is necessary to add three strategies - correct economic disadvantage; deal with stereotypes, stigma and violence; and strengthen the power of action, voice and participation of women. All this means having influence on the political, socioeconomic and cultural structures of some constitutional regimes that, despite all legislative progress, need to keep reconsidering the partnership between patriarchy and neoliberal capitalism. Consequently, parity democracy is about deepening democracy and, on the other hand, 
the social state. In both cases, bearing in mind that half of the population is male and half female, the relationships between them must be based on equal rights and not on hierarchy.

Conflicts of Interest: The author declares no conflict of interest.

\section{References}

1. UN Women. "Progress of the World's Women 2015-2016, Transforming Economies, Realizing Rights." Available online: http:/ / progress.unwomen.org/en/2015/ (accessed on 14 December 2015).

2. Lombardo, Emanuela, and Margarita León. "Políticas de igualdad de género y sociales en España: Origen, desarrollo y desmantelamiento en un contexto de crisis económica." Investigaciones Feministas 5 (2014): 13-55. [CrossRef]

3. Paleo, Natalia, and Alba Alonso. “¿Es solo una cuestión de austeridad? Crisis económica y políticas de géneroen España." Investigaciones Feministas 5 (2014): 36-68.

4. Bodelón, Encarna. “Las leyes de igualdad de género en España y Europa: ¿Hacia una nueva ciudadanía? ” Anuario de la Facultad de Derecho 26 (2010): 85-106.

5. Salazar Benítez, Octavio. "La necesaria transversalidad de la igualdad de género. Un análisis de las leyes autonómicas de igualdad de mujeres y hombres." Revista Vasca de Administración Pública 75 (2006): 161-212.

6. Alonso Álvarez, Alba. El Mainstreaming de Género en España. Valencia: Tirant lo Blanch, 2015.

7. Gil Ruiz, Juana. Las Nuevas Técnicas Legislativas en España. Valencia: Tirant lo Blanch, 2012.

8. Consejo de Europa. "Gender Mainstreaming." In Conceptual Framework, Methodology and Presentation of Good Practises. Estrasburgo: Group of Specialists on Mainstreaming, 1998.

9. Woodward, Alison E. "Too late for gender mainstreaming? Taking stock in Brussels." Journal of European Social Policy 18 (2008): 289-302. [CrossRef]

10. Wittman, Amanda. "Looking local, finding global: Paradoxes of gender mainstreaming in the Scottish Executive." Review of International Studies 36 (2010): 51-76. [CrossRef]

11. Stratigaki, Maria. "Gender Mainstreaming vs. Positive Action: An Ongoing Conflict in EU Gender Equality Policy." European Journal of Women's Studies 12 (2005): 165-86. [CrossRef]

12. Pollack, Mark, and Emilie Hafner-Burton. "Mainstreaming gender in the European Union." Journal of European Public Policy 7 (2000): 432-56. [CrossRef]

13. Meier, Petra, and Karen Celis. "Sowing the Seeds of its own failure: Implementing the Concept of Gender Mainstreaming." Social Politics 18 (2011): 469-89. [CrossRef]

14. McGauran, Anne-Marie. "Gender mainstreaming and the public policy implementation process: Round pegs in square holes? " Policy and Politics 37 (2009): 215-33.

15. Lombardo, Emanuela. "El mainstreaming: La aplicación de la transversalidad en la Unión Europea." Aequalitas Revista de Igualdad de Oportunidades Entre Mujeres y Hombres 13 (2003): 6-11.

16. Alfama, Eva, Marta Cruells, and María de la Fuente. "¿Qué ha cambiado con esta crisis? El mainstreaming de género en la encrucijada." Investigaciones Feministas 5 (2014): 69-95. [CrossRef]

17. Collantes Sánchez, Beatriz, and Amelia Sanchís Vidal. La Evaluación del Impacto de Género en la Normativa Estatal y Andaluza. Jaén: Diputación Provincial de Jaén, 2008.

18. Calvo, Kerman, Marta Gutiérrez, Luis Mena, and Soledad Murillo. “El papel del conocimiento experto en las políticas públicas de igualdad en España." Investigaciones Feministas 5 (2014): 157-83.

19. Rubio Castro, Ana. "Los efectos jurídicos del soft law en materia de igualdad efectiva: La experiencia española." Anuario de Filosofía del Derecho 30 (2014): 37-68.

20. Torres, Concepción. "La fundamentalidad del derecho a una vida libre de violencia de género: La necesidad de un marco jurídico conceptual/despatriarcalizador inserto en el texto constitucional." Themis, Revista de Igualdad de Género 13 (2013): 20-33.

21. Fraser, Nancy. Fortunas del Feminismo. Madrid: Traficantes de sueños, 2015.

22. Harding, Sandra. Ciencia y Feminismo. Madrid: Morata, 1996.

23. Unzueta, María Angeles Barrere. "Versiones de la democracia, feminismo y política radical." In Democracia y Participación Política de las Mujeres. Visiones Desde Europa y América Latina. Edited by Ruth Mestre i Mestre and Yanira Zúñiga Añazco. Valencia: Tirant lo Blanch, 2013, pp. 45-80. 
24. Unzueta, María Angeles Barrere. "Iusfeminismo y derecho antidiscriminatorio: Hacia la igualdad por la discriminación.” In Mujeres, derechos y ciudadanía.. Edited by Ruth Mestre. Valencia: Tirant lo Blanch, 2008, pp. $45-72$.

25. Castro, Ana María Rubio, and Joaquín Herrera Flores. Lo Público y lo Privado en el Contexto de la Globalización. Sevilla: Instituto Andaluz de la Mujer, 2006.

26. Mestre, Ruth, and Yanira Zúñiga Añazco. Democracia y Participación Política de las Mujeres. Visiones desde Europa y América Latina. Valencia: Tirant lo Blanch, 2013.

27. Unzueta, María Angeles Barrere. “La interseccionalidad como desafío al mainstreaming de género en las políticas públicas." Revista Vasca de Administración Pública 87-88 (2010): 225-52.

28. Pazos, María. Desiguales por ley. Madrid: Catarata, 2013.

(C) 2016 by the author; licensee MDPI, Basel, Switzerland. This article is an open access article distributed under the terms and conditions of the Creative Commons Attribution (CC-BY) license (http://creativecommons.org/licenses/by/4.0/). 